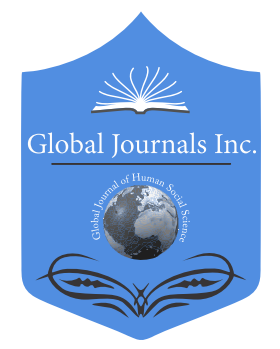

GLOBAL JOURNAL OF HUMAN-SOCIAL SCIENCE: A

ARTS \& HUMANITIES - PSYCHOLOGY

Volume 20 Issue 12 Version 1.0 Year 2020

Type: Double Blind Peer Reviewed International Research Journal

Publisher: Global Journals

Online ISSN: 2249-460x \& Print ISSN: 0975-587X

\title{
Representation of Emerging COVID-19 in Bangladeshi Newspapers
}

\author{
By Mehnaz Hoque \& Sk. Abu Raihan Siddique \\ Jagannath University
}

Abstract- This study explains how Bangladeshi media responded during the coronavirus crisis focusing on the issues of news related to COVID-19. The study analyzes the content of a total of 744 articles in the ProthomAlo \& The Daily Star, the country's most-read newspapers in-between the timeline from 8th March 2020 to 4th April 2020. It investigates how the COVID-19 presented as 'furious' and 'deadly' virus among the readers. In particular, this study explores the representation pattern of the phenomena of 'emerging deadly infectious diseases' in the newspapers. Using Social Representation Theory (SRT), the study investigates the collective meaning sharing focus on the news coverage during the early stage of the COVID-19 outbreak in Bangladesh. The study also finds out how the newspapers sideline the representation of this pandemic as a 'health crisis' to ' national economic crisis.' Thus the representation covers up the government irresponsibility by focusing more on 'unconscious mass' and 'limitations' of a developing country. Therefore, the 'panic' increases and the solution of this pandemic muffled under it. Also, this study provides some tentative explanations for this linguistic representation by editorial sections of these newspapers.

Keywords: COVID-19, pandemic, social representation theory, Bangladesh, newspaper coverage.

GJHSS-A Classification: FOR Code: 890303

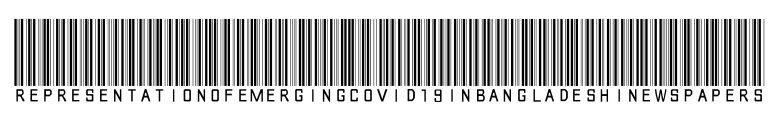

Strictly as per the compliance and regulations of:

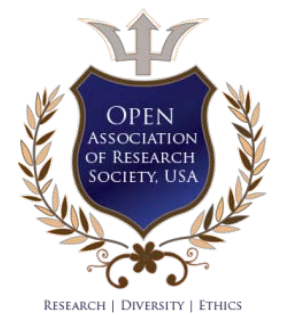

(C) 2020. Mehnaz Hoque \& Sk. Abu Raihan Siddique. This is a research/review paper, distributed under the terms of the Creative Commons Attribution-Noncommercial 3.0 Unported License http://creativecommons.org/licenses/by-nc/3.0/), permitting all noncommercial use, distribution, and reproduction in any medium, provided the original work is properly cited. 


\title{
Representation of Emerging COVID-19 in Bangladeshi Newspapers
}

\author{
Mehnaz Hoque ${ }^{\alpha}$ \& Sk. Abu Raihan Siddique ${ }^{\sigma}$
}

\begin{abstract}
This study explains how Bangladeshi media responded during the coronavirus crisis focusing on the issues of news related to COVID-19. The study analyzes the content of a total of 744 articles in the ProthomAlo \& The Daily Star, the country's most-read newspapers in-between the timeline from $8^{\text {th }}$ March 2020 to $4^{\text {th }}$ April 2020. It investigates how the COVID-19 presented as 'furious' and 'deadly' virus among the readers. In particular, this study explores the representation pattern of the phenomena of 'emerging deadly infectious diseases' in the newspapers. Using Social Representation Theory (SRT), the study investigates the collective meaning sharing focus on the news coverage during the early stage of the COVID-19 outbreak in Bangladesh. The study also finds out how the newspapers sideline the representation of this pandemic as a 'health crisis' to ' national economic crisis.' Thus the representation covers up the government irresponsibility by focusing more on 'unconscious mass' and 'limitations' of a developing country. Therefore, the 'panic' increases and the solution of this pandemic muffled under it. Also, this study provides some tentative explanations for this linguistic representation by editorial sections of these newspapers.
\end{abstract}

Keywords: COVID-19, pandemic, social representation theory, Bangladesh, newspaper coverage.

\section{InTRODUCTION}

T he world was shut down for months in 2020 for the cause of the global pandemic, which was first identified in China. The earliest case was detected on 17 November, weeks before the COVID-19 was emerged as a new virus, according to the Chinese press (The Guardian, 2020). Since that (COVID-19) outbreak in Wuhan, China, the global media started showing interest in this, and it increased far more after the declaration of a pandemic by WHO. And the media tries to draw mass consideration through its coverage of any pandemic and try to influence public opinion (Atasoy, 2020). Therefore, after this outbreak, the mass media of Bangladesh also started to disseminate information about the coronavirus after its outbreak in china. On March 7, the country confirmed the first COVID-19 case in its territory (Anwar et al., 2020). The first three known cases were reported on 8th march 2020 by the country's epidemiology institute, IEDCR (IEDCR, 2020). On March 25, through Prime Minister Sheikh Hasina's address to the nation, Bangladesh declared the enforcement of lockdown for ten days from

Author a $\sigma$ : Lecturer, Department of Mass Communication \& Journalism, Jagannath University, Dhaka, Bangladesh.

e-mail:mehnaz@mcj.jnu.ac.bd, raihan@mcj.jnu.ac.bd the next day. Her speech of $25^{\text {th }}$ March 2020 is considered to be the main policy framework of her government incorporating social, health, and security measures in this battle with COVID-19. The idea of this study emerged from the coverage given by the media after taking the very first step by the government after the declaration of the official corona case.

\section{ReseArCH Background}

With an increasing number of affected people, the pandemic of COVID-19 has spread day by day over the whole nation. It was then easy to assume that the country would struggle to combat the spread of the disease, as it has got one of the world's most densely populations. The government then took some immediate measures to fight against the pandemic by declaring to go for lockdown and also prepared some needy steps of creating awareness, keeping this syndrome away from the people. As media started to portrait the issue through their content, newspapers in Bangladesh had also put their attention to highlight the effects, and it was then the top talked issue over the country. Millions of readers were involved through the language that reflects the opinions of the particular newspapers than what people think about related to the virus. Some of the selected topics like social distancing, lockdown, isolation, travel bans, economic crisis, and deaths were started to narrate by the newspapers repeatedly. People became curious, and coverage of the outbreak has consumed much of the news media's attention as people look for information in time for high anxiety and uncertainty. People started to move towards fear, panic, and uncertainty at their subconscious mind, and no doubt newspapers had set the image over their content.

Throughout the world, researchers tend to identify the language of media most that represents the pandemic. Recent studies show the way like how the media intends to represent the COVID-19 virus as a global health crisis or to understand the public perception. None of them tend to analyze the tone of the newspaper on this emerging virus yet. In this study, we will investigate the way on how the popular dailies in Bangladesh presented COVID-19.

The research tries to answer the following questions-

1. What is the rate of presenting the COVID-19 in mainstream newspapers, and what type of news are being focused? 
2. What are the key issues used in the newspapers?

3. Is there any intention to frame the COVID-19 as a threat to the national crisis?

This research is necessary to identify the news tone of Bangladeshi newspapers and will find the answer if they have the intention to play a proper watchdog role by showcasing the limitations taken by the authorities.

\section{ili. Literature Review}

Since 1980 metaphorical framing was widely used to analyze the infectious disease in the social context, especially in the case of HIV/AIDS. Many have focused on the militaristic language used to report and explain this illness, a type of language that has permeated discourses of immunology, bacteriology, and infection for at least a century (Wallis \& Nerlich, 2005).

Like this, in 2003, another epidemic named 'SARS' spread across several parts of the world. It (SARS) was an important news story at that time. But the main source of the news was 'WHO,' and the angle was 'human interest.' And the WHO was setting the news agenda and giving importance to scientific successes: this was a key area that involved major contributions from the UK and the US. The media's combined emphasis on human interest and medical research and responses appears in the early coverage of this epidemic (Kinsella, 1989; Donovan, 1992).

In another article, 'Disease metaphors in new epidemics: the UK media framing of the 2003 SARS epidemic' examines how language and metaphor were used in the UK media's coverage of Severe Acute Respiratory Syndrome (SARS). By analyzing the news on SARS of five major national dailies during the epidemic of spring 2003, the researcher did not found any militaristic language; rather, the key metaphor was 'SARS: a killer.' SARS, as a killer, was an entity, not a force. It was a new interpretation of disease after HIV/AIDS (Wallis \& Nerlich, 2005).

'Representations of SARS in the British Newspapers' was another study that analyzes the representation of SARS as a 'dangerous threat' to the UK public, using the mechanism of 'othering' as the Chinese were so different to 'us' (European). In this way, the SARS scare was disseminated in the international media. Yet this study also shows the difference in the coverage of SARS with earlier epidemics. In particular, this study examines the phenomena of 'emerging, and re-emerging infectious diseases' over the past 30 years and that impacted the faith that Western biomedicine could 'conquer' infectious disease (Washer, 2004).

The 2014 Ebola outbreak in West Africa and the subsequent diagnosis of a case in a Dallas hospital in the US emphasized the nature of 21 st Century challenges in global health. The researcher found that the media emphasis on preventing Ebola from entering the United States, and the Dallas hospital's failure to detect the Ebola case. So the media places value in the American social order than West African human need of health care (Atasoy, 2020) (Aranda, 2019)

Later, in 2019 a new coronavirus was identified that originated in China ( $\mathrm{Li} Q$ et al., 2020). On 30 January 2020, the International Health Emergency and on 11 March, the World Health Organization (WHO) declared the outbreak as an international public health emergency. Atasoy (2020), in his study, 'Representations of COVID-19 pandemic in German \& Spanish newspaper headline: A comparative study' analyze the headlines of highest circulation center-left daily newspapers Süddeutsche Zeitung and El País, that deal with coronavirus (COVID-19) pandemic. The headlines have been examined with the CDA methods of Teun van Djik (2013). The study proves that both newspapers intend to frame the COVID-19 virus as a 'global health crisis.' Subsequently, a negative representation of coronavirus is directly related to china in both newspapers of both countries.

According to Pew Research Center's (2020) survey conducted from March 10-16, 2020, Americans give the news media good marks for their coverage of COVID-19, though most think their reporting has exaggerated the risks. Misinformation has also found its way into the information stream. The findings come from a survey of 8,914 U.S. adults who are members of the Center's American Trends Panel.

On the other hand, UK tabloids Daily Mail and The Sun shared conspiracy theories and they introduced hatred toward Chinese people, implying that the Chinese people are to blame for the outbreak for eating bats and other animals (Daily Mail Online, 2020).

The epidemics are always global as they always travel around the world with people. And the spread of COVID-19 was facilitated by the modern availability of travel and by economic globalization. So the whole world was affected at a time, so to Bangladesh. But the Bangladesh government has taken steps to reduce its effect just after the first case was detected. However few government ministers, including the health minister, said that the government is ready to tackle the crisis. Therefore, some of the cabinet ministers' remarks on COVID-19 have made the government uncomfortable (The Daily Star, 2020).

Ayesha Siddika \& Md. Didarul Islam (2020) attempt to understand the public perception in Bangladesh regarding the measures taken by the government. The study has found that the measures taken by the Bangladesh government should have been taken earlier and more robust measures are necessary to stop this pandemic. The study also shows that government authorities partially failed to communicate the measures of the government to the wider public audience. Moreover, this research finds that proper 
coordination among all the agencies would help to contain the disease with a continuous lockdown and social distancing policy.

In this situation, it is the primary duty of media to play a watchdog role. The main objective of this research is to explore the representation of COVID-19 in the most circulated newspapers in Bangladesh, whereas the researchers have selected the 'ProthomAlo' and 'The Daily Star' as the sample to investigate the trends. So through investigating the framing of an emergent disease in these newspapers, researchers can also contribute to theorizing it.

\section{Methodology \& Theoretical BACKGROUND}

According to IEDCR, the first cases were confirmed in the country on 8 March, and the lockdown began in Bangladesh on 26 March. The research considered the first four weeks after 8 March 2020 to understand the news coverage pattern of COVID-19 in the ProthomAlo and The Daily Star.

To conduct the study, researchers have chosen the ProthomAlo, the most read vernacular daily with 6.6 million circulations in a day (ProthomAlo, 2018) and The Daily Star, the largest circulated English daily as the sample. These newspapers were selected based on highest readership; therefore, researchers acknowledge that these findings would not be able to generalize to all newspapers of the country.

The study integrates content analysis of the headlines to analyze the representation of COVID-19 the mainstream newspapers of Bangladesh between 8 March 2020 to 4 April 2020. And for better understanding researchers also analyze the editorial and opinion part of both newspapers. The main reason of this sampling is to find out the coverage pattern of Pandemic during this outbreak in Bangladesh.

'Social Representation Theory' is used to portrait the representation of COVID-19 as an emerging threat in Bangladeshi newspapers. The SRT refers to the process of collective meaning sharing focus on phenomena. As a theory of communication, it links society and individual, media, and public. Hoijer (2011) describes, 'the theory is relevant for media-and communication representing how media texts deal with and present national, regional and social issues and events to the audience.' According to Bauer \& Gaskell (1999), 'Representations are embodied in communication and individual minds, shared in a way similar to language.' In this research, researchers attempt to focus on the media representations rather than measure what the public generalize or even think in the way that a 'media effects' approach would.

The researchers have analyzed the content of a total of 744 news in both newspapers. All the news has been taken from the online version of the two most circulated newspapers in this country. The researchers have used the timeline from $8^{\text {th }}$ March 2020 from $4^{\text {th }}$ April 2020 , the first month of the outbreak in Bangladesh. The researchers found that the ProthomAlo published 387 news (52\%), and The Daily Star published 357(48\%) news within the timeline.

Table 1: News sample for the study

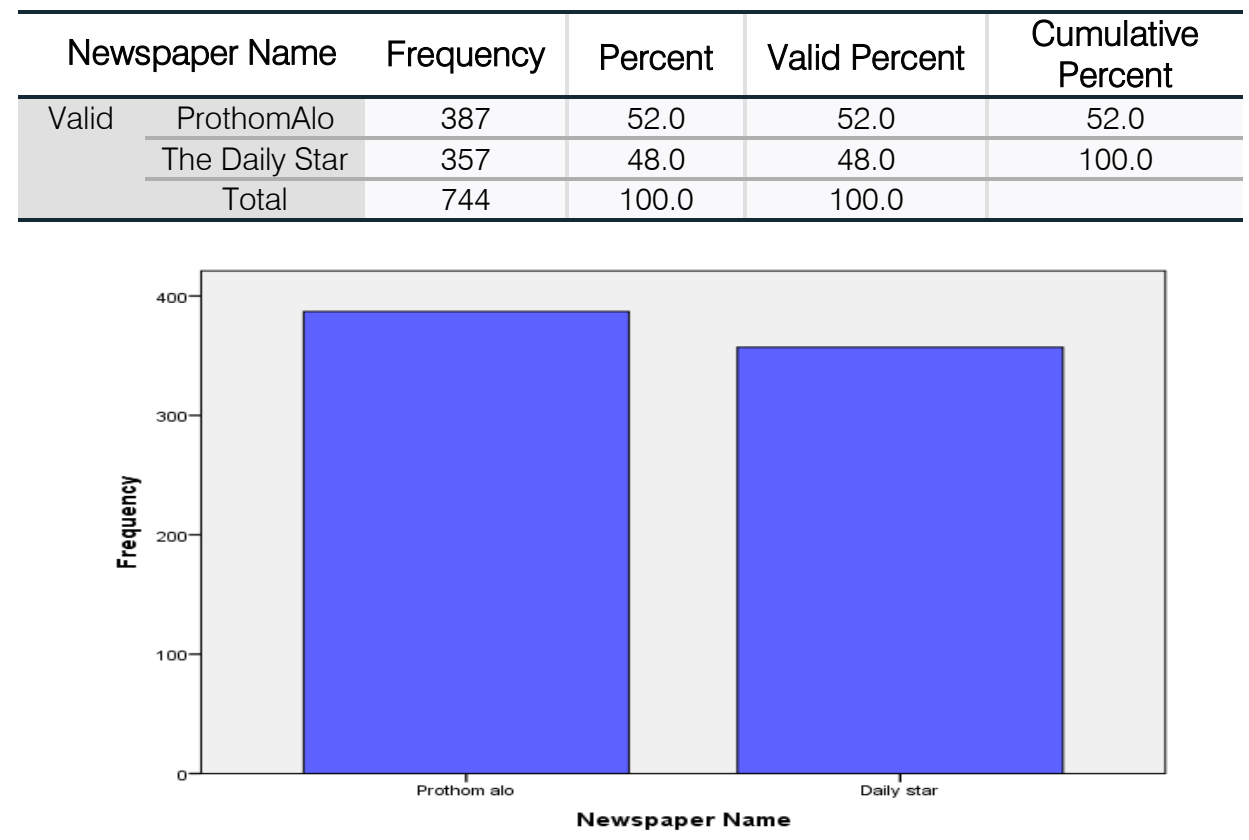

Chart 1: News sample for the study 
To analyze the data, researchers have constructed a coding schedule with different categories such as publication date, headline, news types, issues of the news, page number to monitor, and analyze. All the contents were then analyzed using Statistical analysis Package for Social Sciences (SPSS), with the selected coding schedule.

\section{Discussion}

\section{a) Headline Analysis}

Before starting to read any news, readers always glance over the headline, as the headlines always showcase the keywords of the news, which makes the readers easy to understand the key issues of the news. This study finds that around $16 \%$ of total news has used the concept of 'fear' in the headline. The ProthomAlo used the concept of 'fear' in 77 headlines, and The Daily Star used it in 44 headlines. Among other issues, the threat $(8.2 \%)$, deadly virus $(5.8 \%)$, the effect on the economy $(7.4 \%)$, safety precautions $(7.8 \%)$, optimism (6.2\%), unconscious mass (4.6\%) \& steps taken by the government (4.2\%) are mostly used during the sample period. In this representation, only the headlines related to step taken by the government $4.2 \%$ (31 headlines), optimism 6.2\% (46 headlines) and safety precautions $7.8 \%$ (58 headlines) were giving the way out from this crisis; rest of the news highlighted this virus as furious one.

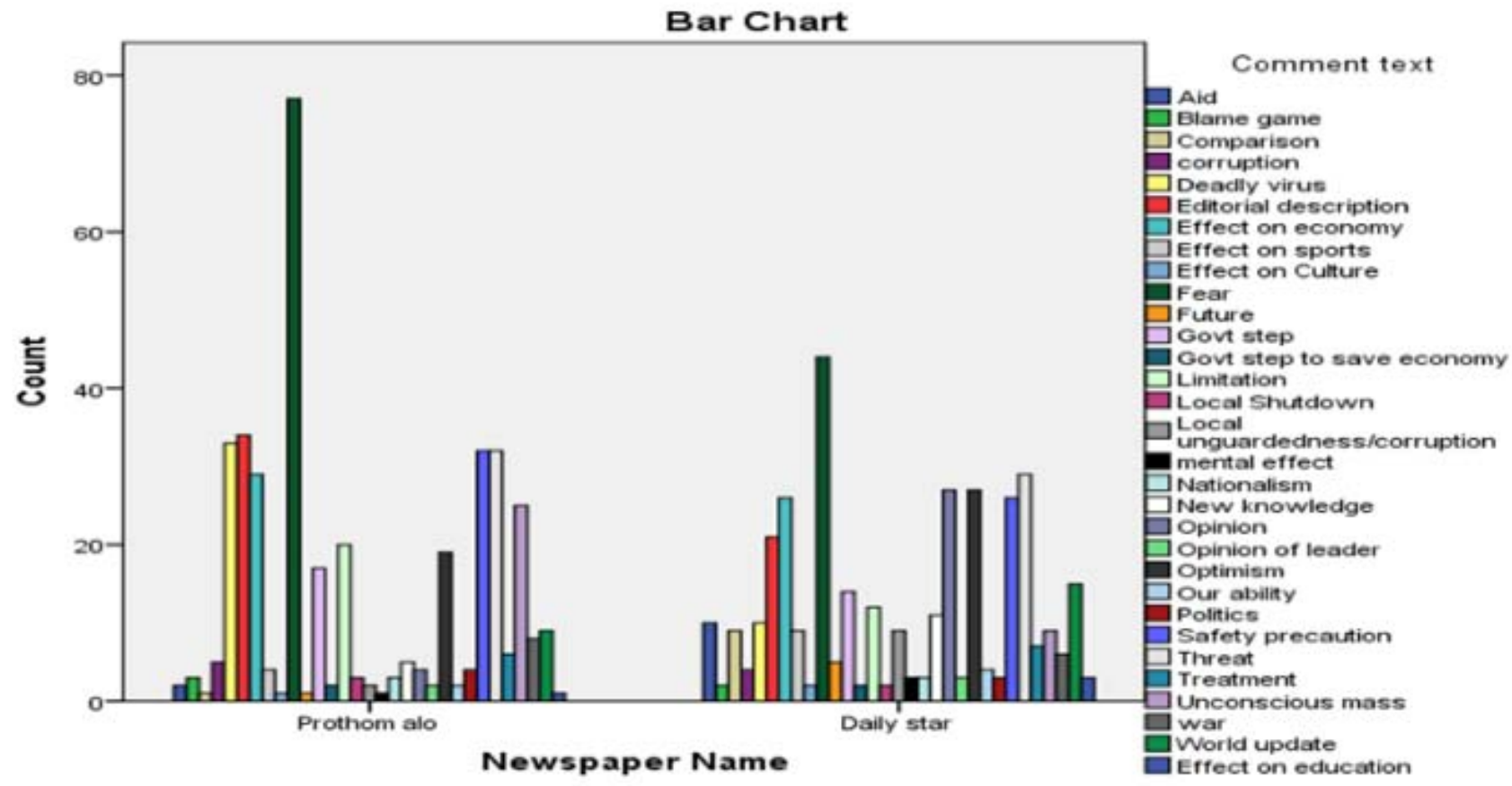

Chart 2: Summary of the key issues of news headlines tagged with COVID-19

On an Individual newspaper assessment, this study finds that the ProthomAlo gave the highest preference to 'fear' (19.9\%) in the headline while the Daily Star used fear (12.2\%) and threat (8.2\%) respectively. Analyzing this, researchers find the ProthomAlo giving more importance in creating 'fear' among its readers. But, both newspapers were giving equal importance on the economic effect of coronavirus, where researchers see the ProthomAlo mentioned this matter for $7.5 \%$ on its headline, and the percentage rate of The Daily Star was $7.3 \%$. In addition, both newspapers had an intention to avoid the term 'blame game' $(0.7 \%$ in both of the newspapers) and 'political affiliation' $(0.9 \%$ in both of the newspapers) in their headlines.

On the other hand, The Daily Star had an intention to give more importance to 'new knowledge'
(The Daily Star 3.1\%) about coronavirus than that of the ProthomAlo (1.3\%). The same goes for the headlines related to the country's capability (ProthomAlo 0.5\% \& The Daily Star 1.1\%) and the future prospect of COVID19 (ProthomAlo 0.3\% \& The Daily Star 1.4\%). These indicate that The Daily Star was trying to represent COVID-19 as a less furious disease than that of the ProthomAlo. Moreover, the ProthomAlo tried to create fear among the unconscious mass (6.5\%), images of deadly virus $(8.5 \%) \&$ threat (8.3\%) in its headline.

In another case, both newspapers paid less attention to the headline related to 'corruption' to the COVID-19; the ProthomAlo 1.3\% \& The Daily Star 1.1\%.

This study also finds that there was a marked shift to use the idea 'fear' within the timeline. In the beginning, the newspapers did not use any words that 
created 'fear' very much, but after the declaration of the official locked down on March 25, when COVID-19 spread all over Bangladesh, these ideas of creating fear pop up more frequently on the headlines of the news. (Chart 3)

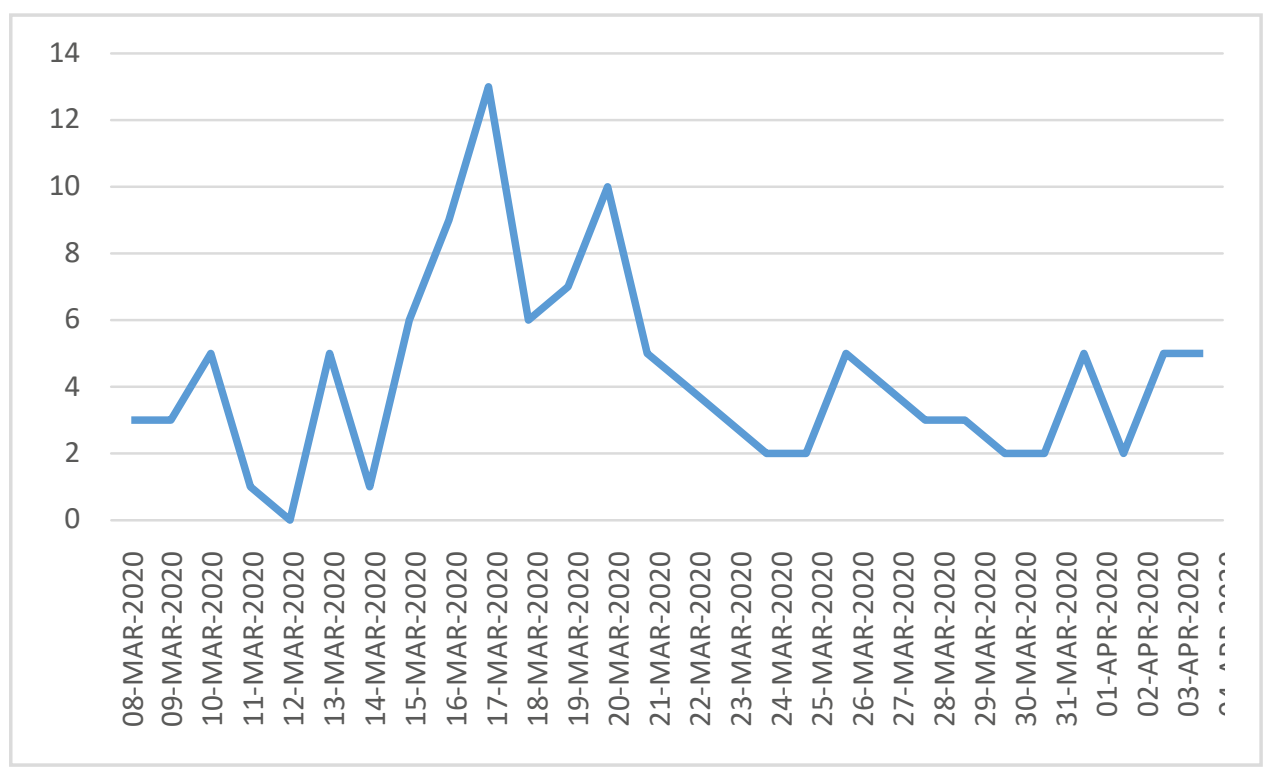

Chart 3: Timelines of news headlines tagged fear described in COVID-19 news

b) Timeline Analysis

According to Chart-4, the study finds that both dailies started to publish more COVID-19 related news from mid-March, just before the declaration of locked-down by the government.

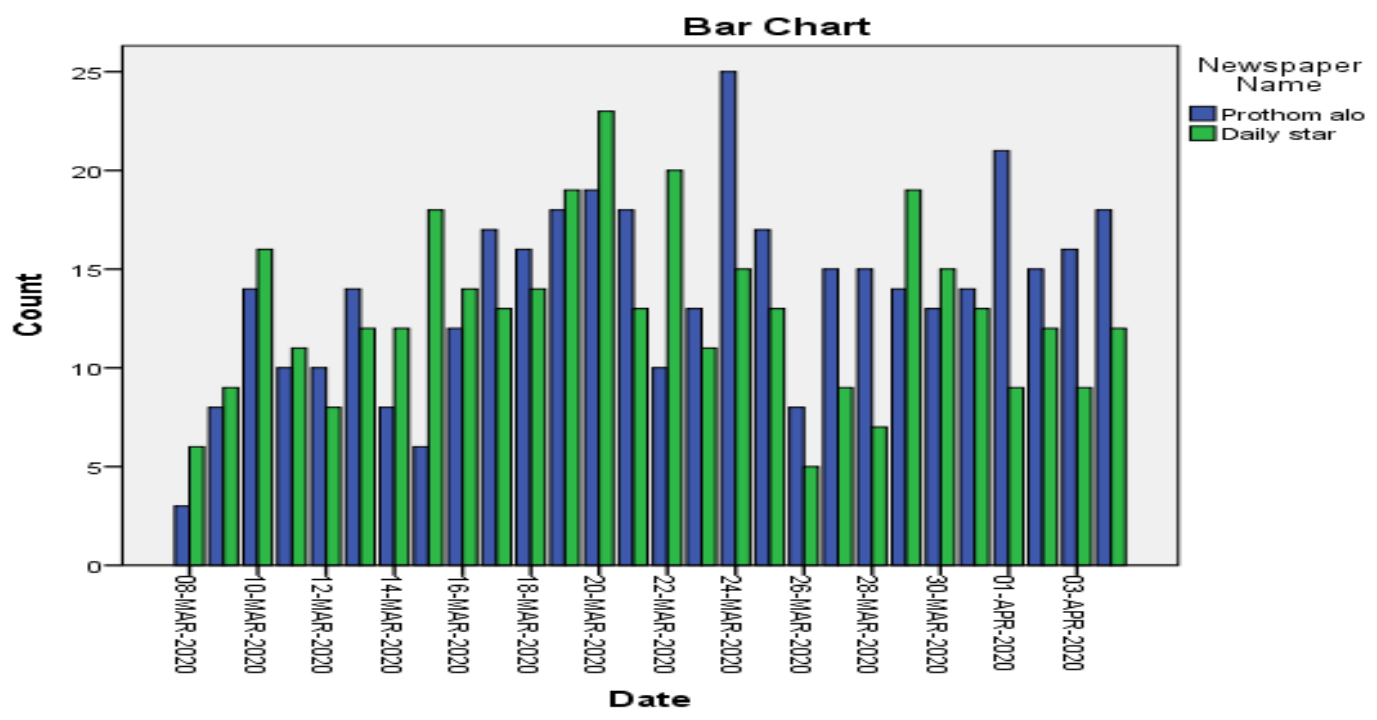

Chart 4: Timelines of news headlines tagged with COVID-19

To analyze the timeline of the most popular vernacular daily ProthomAlo, researchers found that the daily always had an intention to present the national news related to COVID-19 most. But during late-mid March (18 March- 24 March), the national news about COVID-19 was given higher preference, but the news related to the world was also getting almost equal treatment to the ProthomAlo. (Chart 5) 


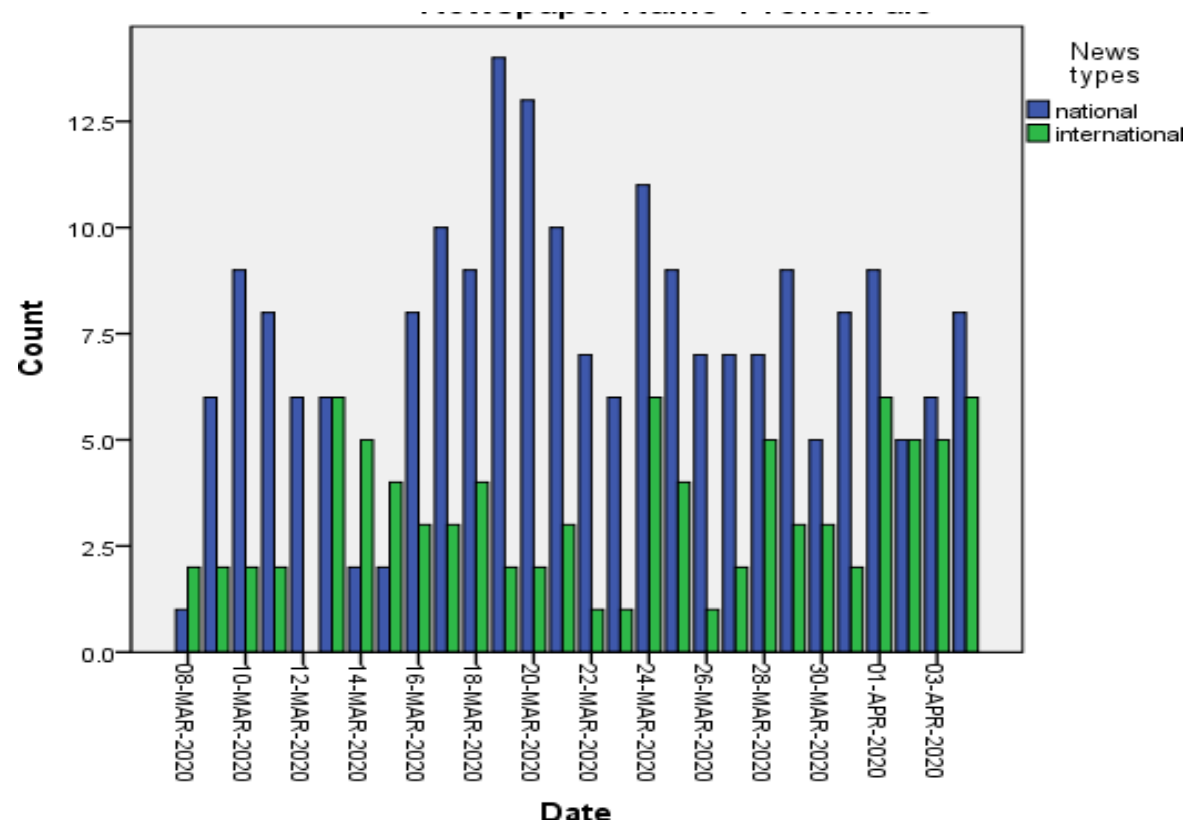

Chart 5: Timelines of national \& International news headlines tagged with COVID-19 (ProthomAlo) the declaration of locked-down, other than that international news got good treatment in this newspaper.

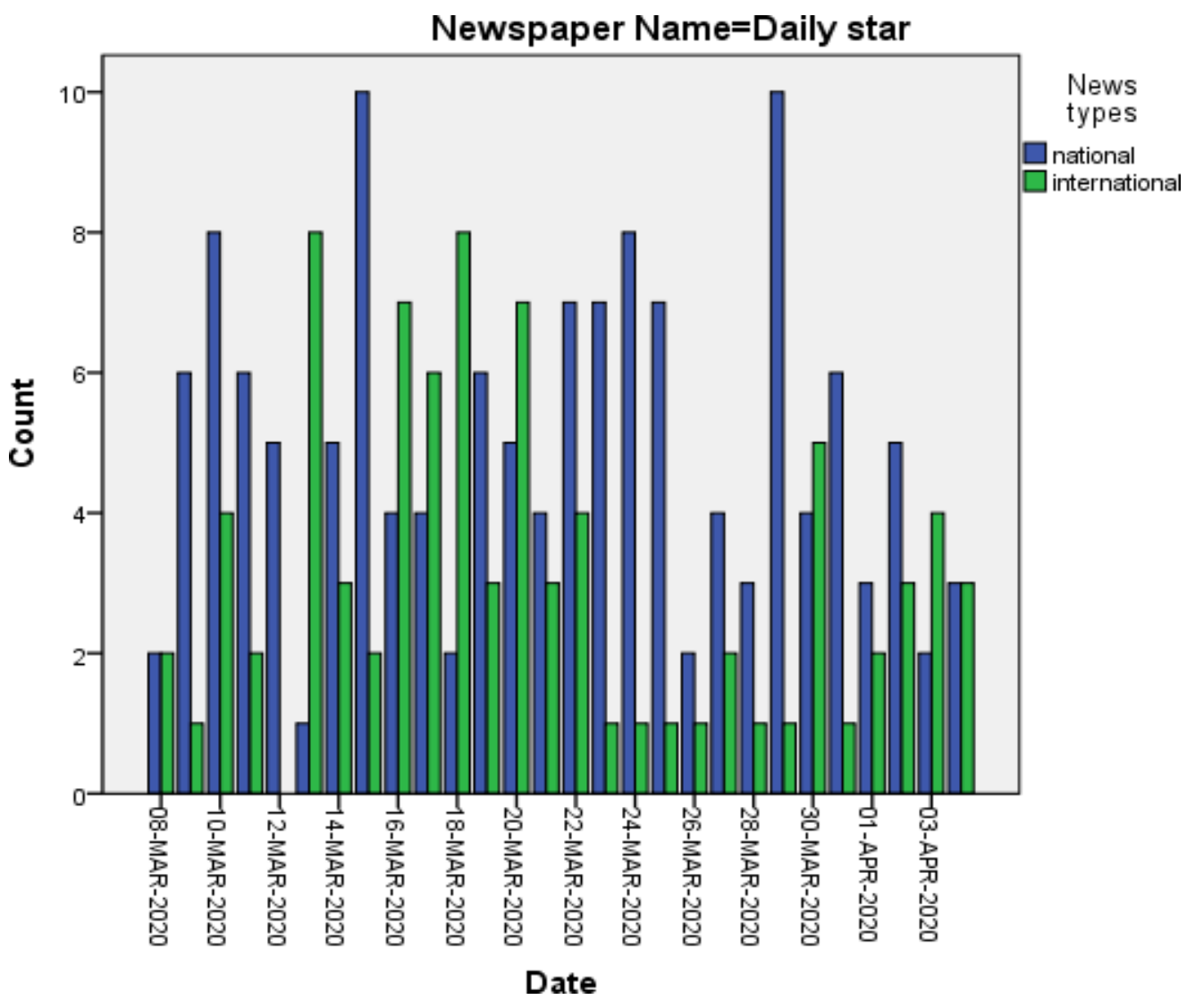

Chart 6: Timelines of national \& International news headlines tagged with COVID-19 (The Daily Star) 
As per chart 7, researchers found that during locked down declaration time and just after the declaration, The Daily Star published more national news than the ProthomAlo.

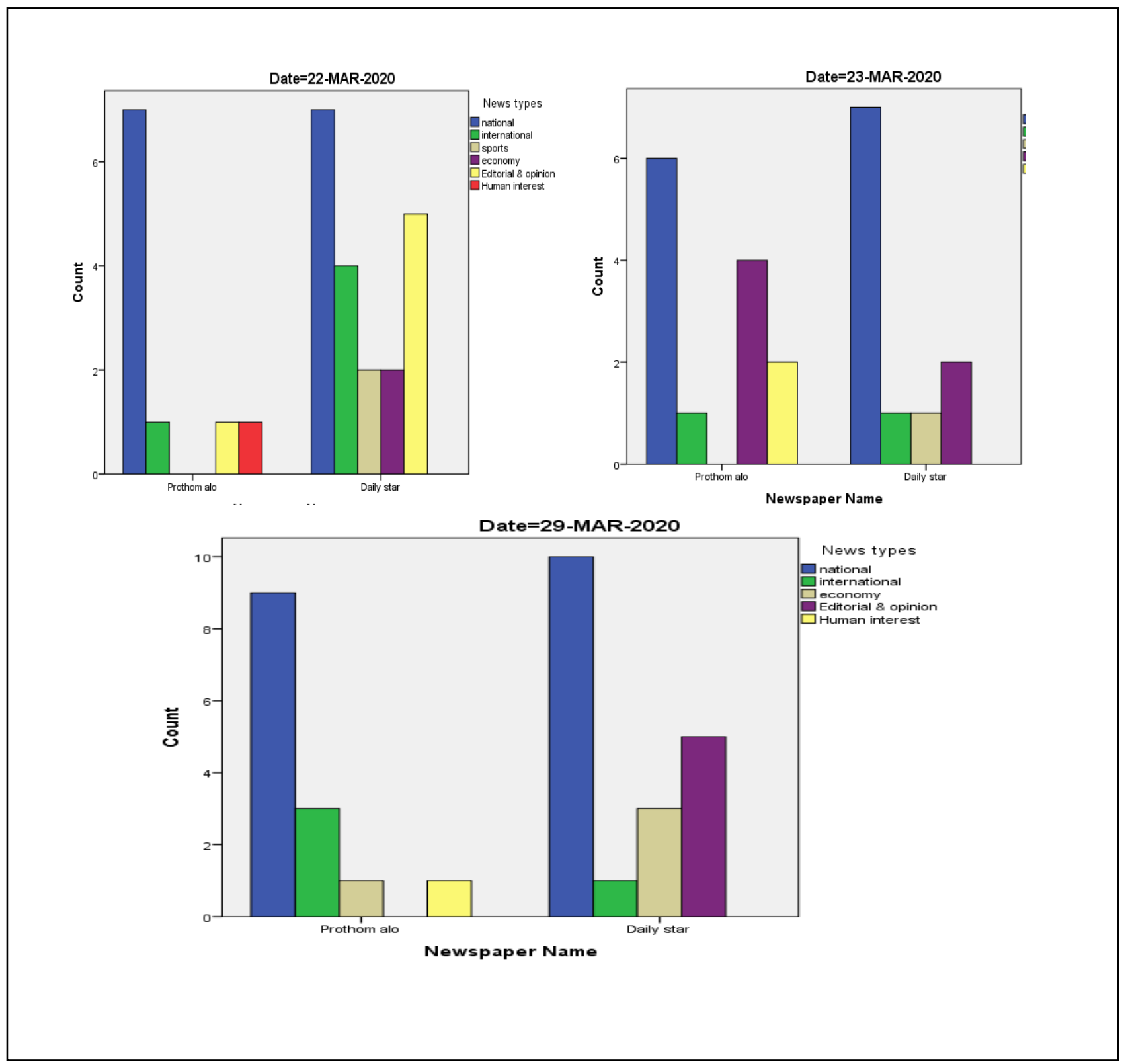

Chart 7: Timeline of published news as per types

\section{c) News types analysis}

To explain this media framing more precisely, this study has also analyzed the news types by analyzing the headlines. The researchers found that the ProthomAlo published 208 (53.7\%) national news, and The Daily Star published 139 news (38.9\%) among 347 published news about coronavirus within the sample period. Both newspapers published an almost equal number of international news related to COVID-19; the ProthomAlo 23.3\% \& The Daily Star 24.1\%. But The Daily Star gave importance to the news related to economic effect, $11.8 \%$ (The Daily Star 42 news \& the ProthomAlo 26 news) and the ProthomAlo gave more preference to the news with human interest, $4.1 \%$ than that of The Daily Star (the Prothom Alo 16 news \& The Daily Star 2 news). 
Table 2: Newspaper Name * News types Cross tabulation

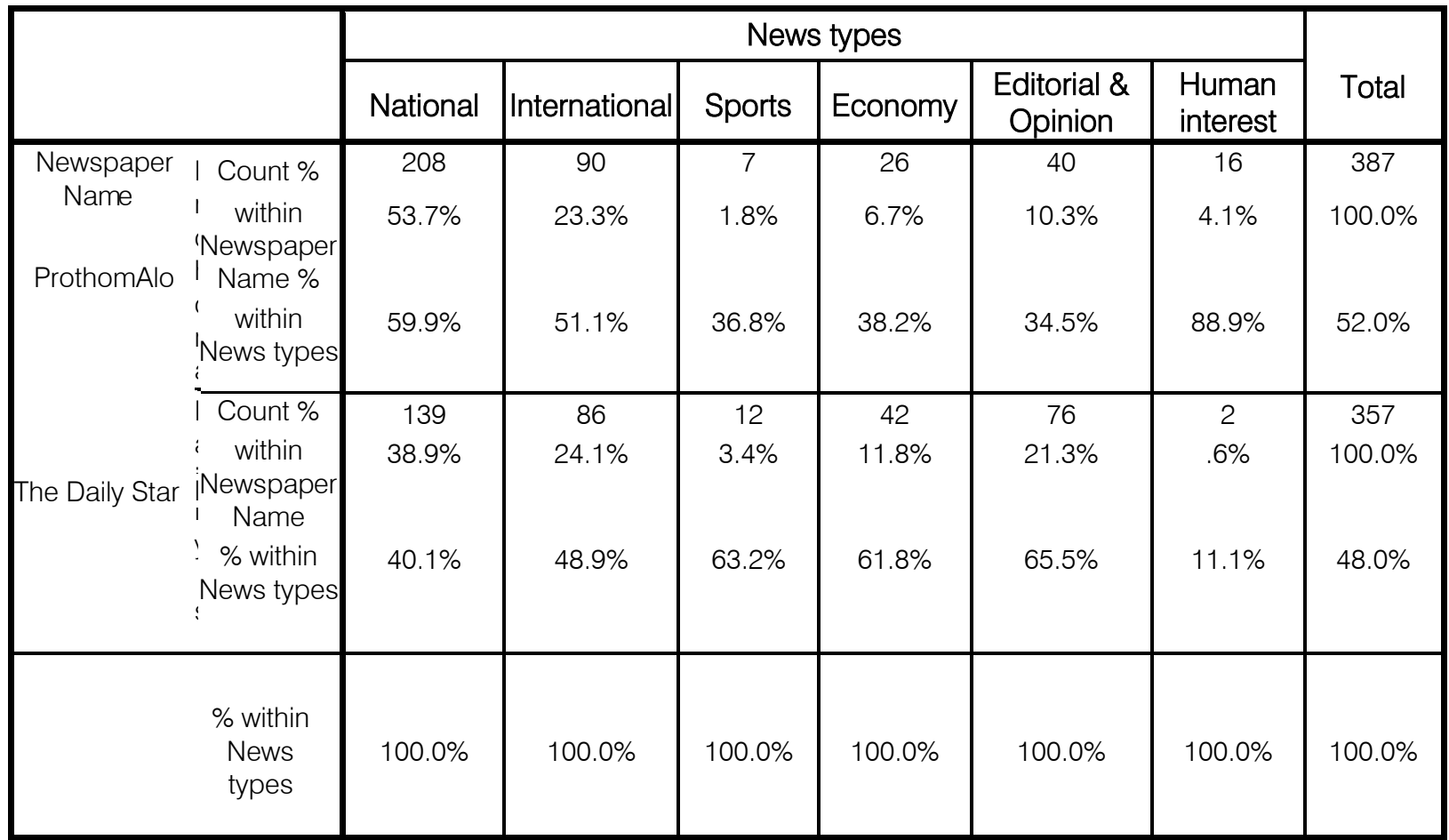

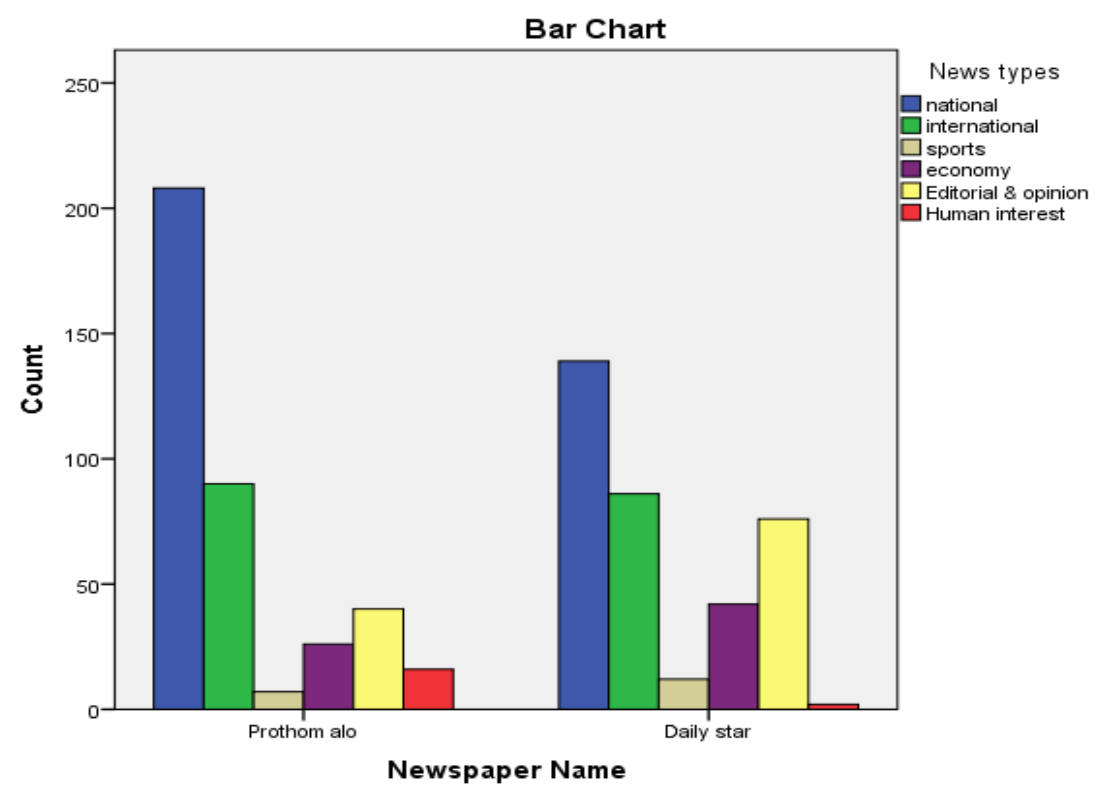

Chart 8: Summary of types of news according to headlines tagged with COVID-19

Among total 347 national news, we see the highest issues were related to 'fear' (22\%), unconscious mass $(8.1 \%)$, threat $(6.3 \%)$, safety precautions $(12.4 \%)$, limitations (7.2\%), and government steps (8.1\%). It proves that the dallies are creating a culture of fear among the unconscious mass of Bangladesh, and try to deliver them the knowledge of safety precautions and the steps taken by the government to fight with COVID-
19. On the other hand, the main issues related to economic news were the effect of COVID-19 on the economy $(74.5 \%)$. 


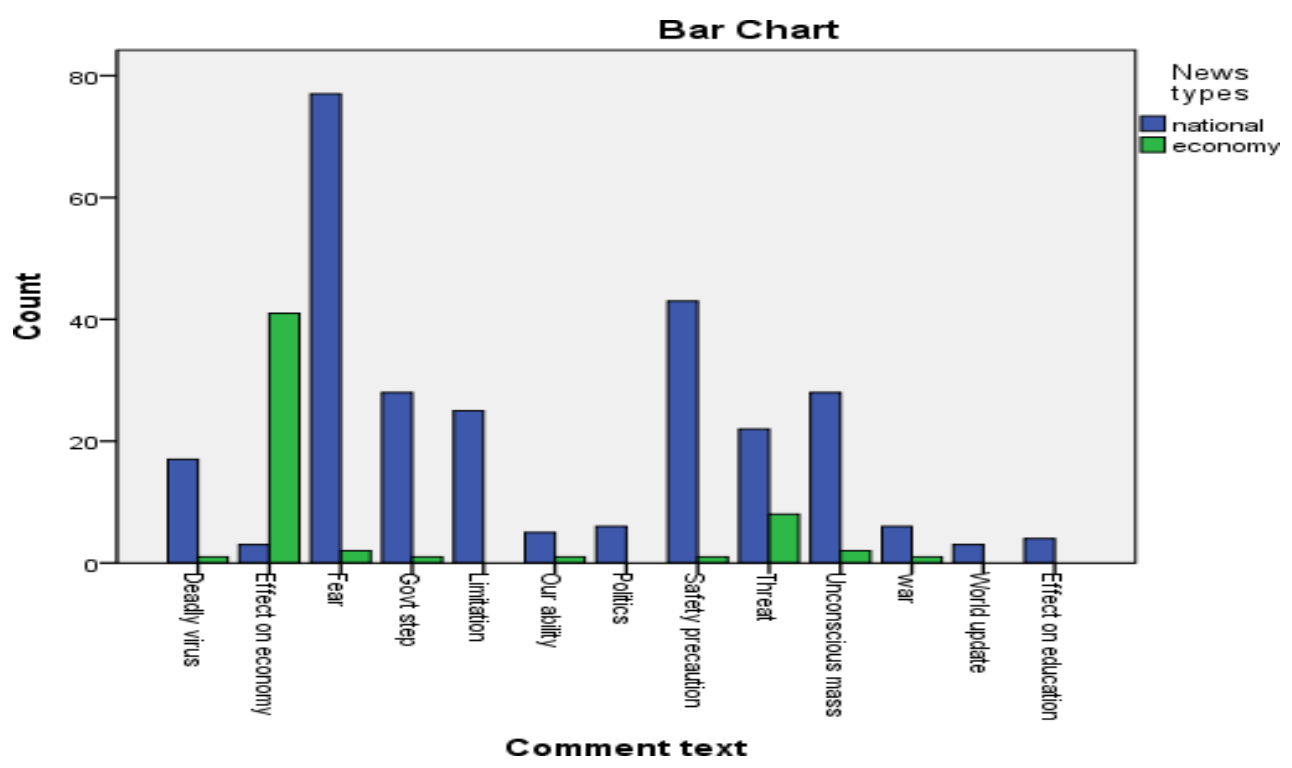

Chart 9: Summary of the main focus in news headlines in national \& economic news tagged with COVID-19

Among total 176 international news, the issues that focused, again and again, were fear (17.6\%), deadly virus $(13.1 \%)$, threat $(14.2 \%)$, world update

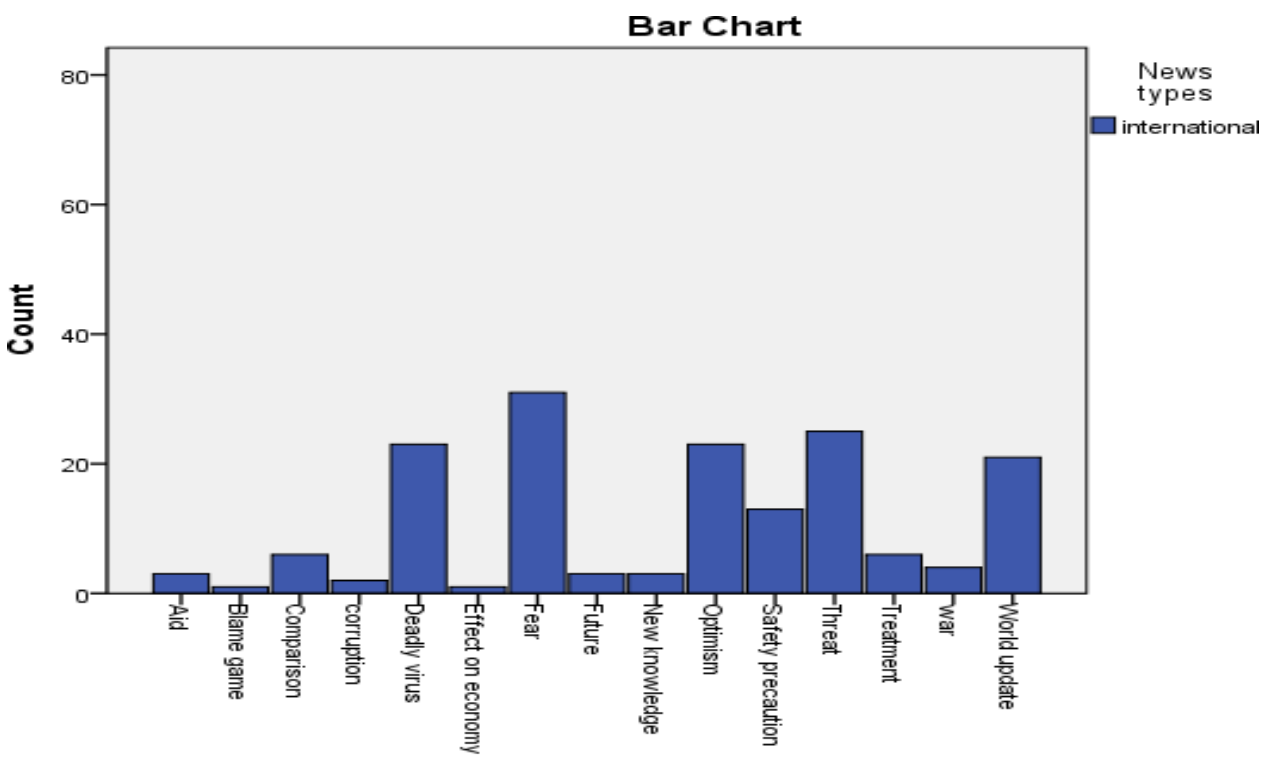

Chart 10: Summary of the main focus in news headlines in international news tagged with COVID-19

According to the table 3 and chart 10 , the ProthomAlo gave importance to the news with 'human interest' $4.1 \%$, that talked about the struggle of less wealthy people, garments worker, slum dwellers (total 16 stories) and The Daily Star published only two news about the struggle of lower-income people and slum dwellers rather its preference was to highlight the economic news $11.8 \%$ (42 stories). It proved that the mass people of Bangladesh are the reader of Prothom Alo, but The Daily Star is not a daily of mass people of Bangladesh as it acts as the mouthpiece of the higher class.

(11.1\%) \& optimism (13.1\%), that reinforced the idea of pandemic crisis all over the world.

Bar Chart 
Table 3: Newspaper Name * News types cross tabulation

\begin{tabular}{|l|c|c|c|}
\hline \multicolumn{2}{|c|}{} & Human interest \\
\hline \multirow{2}{*}{ Newspaper Name } & ProthomAlo & Count & 16 \\
\cline { 3 - 4 } & & \% within News types & $0.9 \%$ \\
\cline { 3 - 4 } & The Daily Star & Count & 2 \\
\cline { 3 - 4 } & & \% within News types & $0.1 \%$ \\
\hline
\end{tabular}

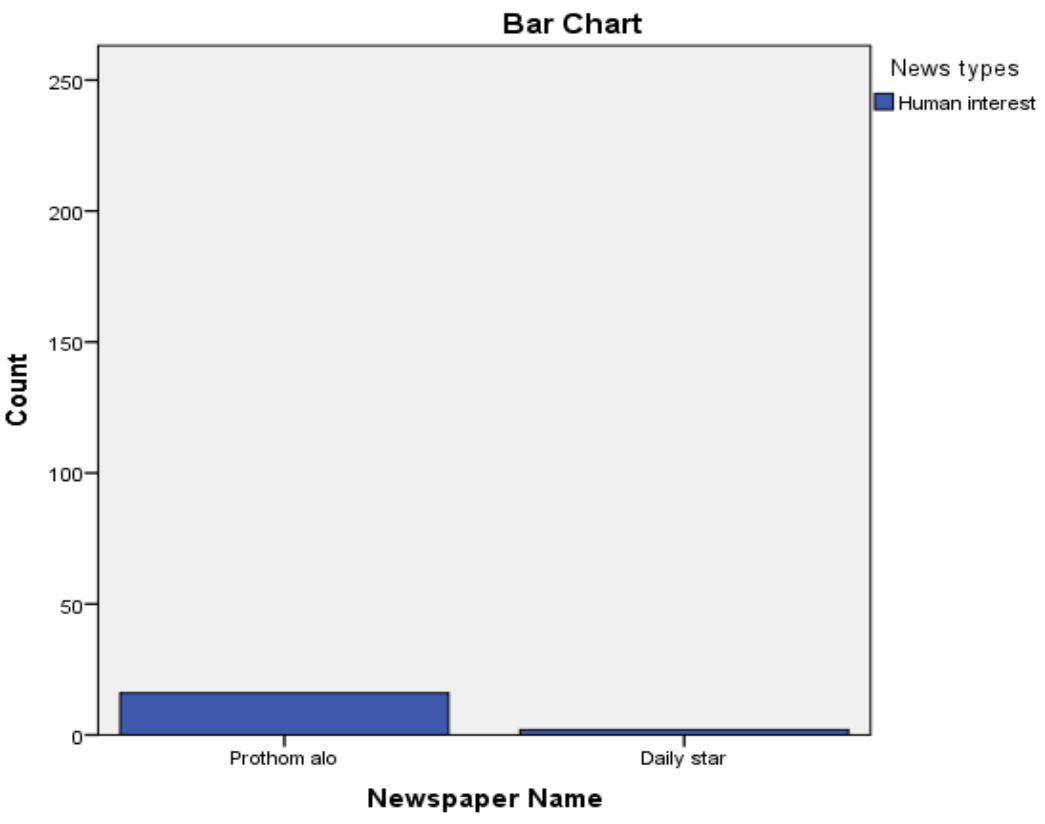

Chart 11: Summary of human interest focused news headlines related to COVID-19

\section{d) Editorial \& Opinion Analysis}

After analyzing the editorial pages of both newspapers, researchers found that the Daily Star published more editorial and opinion 21,3\% (total 76) than the ProthomAlo 10.3\% (total 40). The study also found that, after the detection of the very first affected case in Bangladesh, The Daily Star started to set the tone on this emerging virus on its editorial section on a regular basis, highlighting 'crisis situation,' 'limitation,' 'mass awareness,' 'unconsciousness,' 'struggle,' 'government steps,' 'economic aspects,' 'human interest,' 'local corruption,' 'strategy,' 'opportunity' and the terms 'fear' and 'panic' as well. On the other hand, the ProthomAlo was eager to put attention on government activities on its editorial most, while we see 'human interest' story, 'limitation', and 'mass awareness' in its editorial section. Analyzing the editorials, both the national dailies focused the words 'fear' and 'panic' most but not to disseminate the fear among the people but repeatedly urging the government to take proper steps to minimize the harms. 


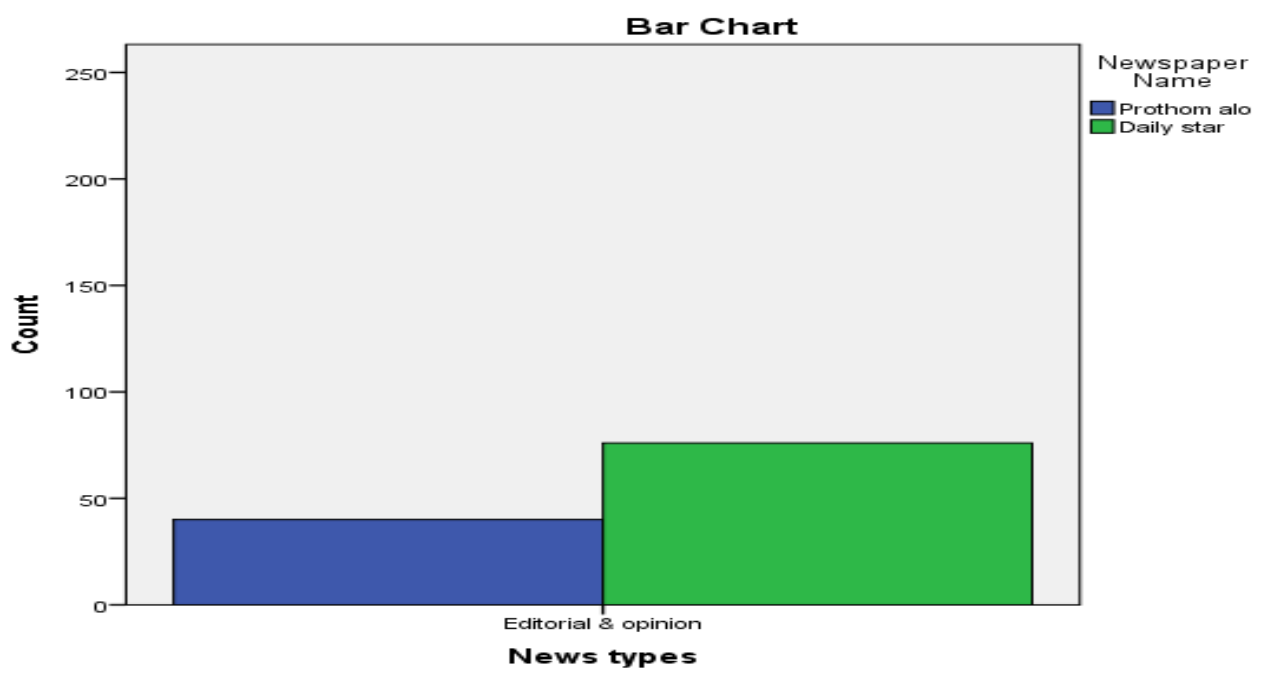

Chart 12: Number of Editorial and opinion in both dailies

By the first week, indicating the 'crisis situation' The Daily Star on its editorial (10 March 2020), repeatedly remembered the role of government during this kind of pandemic and questioned on healthcare facilities over PM's assurance that we are well prepared to protect the transmission.

In the same week, researchers see ProthomAlo giving less preference over the issue on its editorial. On March 10, the very first editorial was set by the dailies after the first confirmed case. On that editorial, it has set the tone by analyzing the government's initiative to overcome the situation. The newspaper questioned government's activities as the government was repeatedly saying that they are well prepared to protect the transmission but yet to see any precautionary measures. Indicating the term 'limitation,' the daily expressed its concern over averting the virus among the public setting the tone like: 'Needs to formulate guidelines, especially for the educational institutions and the public transport' and repeatedly asked the authorities for taking steps to reduce the blast of COVID19 pandemic on its next editorial on 14 that month.

There was a marked shift in the coverage of COVID-19 in the editorial section of ProthomAlo, by the third week. On March 22, the daily set the editorial, mentioning the authorities to protect our frontline healthcare worker on priority base by supplying personal protective equipment (PPE) and other protective equipment. Indicating the term 'limitation', the editorial also focused on the careless motive of the authorities. The daily also mentioned that actual information needs to provide among the mass people to create 'mass awareness' on its following editorial. On March 23, the ProthomAlo had set its editorial mentioning the term 'war', as we need to initiate a proper formula to face the war and also mentioned that the government had a lot to do wining against the war. On that week, the
ProthomAlo again urged the government to take proper initiative by creating awareness, supplying medical equipment, and assuring social distancing.

By last week on March 29, The Daily Star on its editorial identified the term 'local corruption,' marking the medicine businessman as 'unscrupulous.' Urging the authorities to take urgent measures, the tone was, 'Stop hiking prices of medicines.' On another editorial, it thanked the government for taking timely steps of going for the shutdown. In another editorial, the daily had praised the government's initiative to save the economy, highlighting the term 'government steps to save the economy.' On April 4, the daily established the headline as, 'Covid-19 crisis warrants a comprehensive, strategic rescue plan,' and described that PM's stimulus package would create 'far-reaching effects.'

In the last week, the ProthomAlo had set the tone on its editorial highlighting the treatment facilities, the limitation as well as the government and private actions regarding that. On those editorials, the daily urged to set up more dedicated COVID hospitals, to ensure proper medical facilities and asked to increase the testing as much as possible. On April 2, the ProthomAlo solicited the government to ensure foods to the indigent, as we faced scarcity of food due to the lockdown. Here we see the element 'human story', which may arise a tension over the situation, but the daily had presented it showing a solution to overcome the tackles.

\section{FINDINGS}

This study has explained the role of Bangladeshi newspaper to cover the issues tagged with COVID-19 in the coronavirus crisis. It revealed that all the published articles during sample time were more national focused. Therefore, both newspapers 
presented COVID-19 as a 'furious' virus. The dailies focused on 'fear' and 'threat', urging the government to take proper steps to minimize the harms. Media portrays of this pandemic as a dangerous disease to death increases during the declaration of 'shut-down' by the prime minister of Bangladesh. When journalists write an article on corona as a fearful one, they always focus on the death ratio and the unconscious mass of Bangladesh. That increases an unknown fear among reader as they got to know that the people around them are not conscious of this deadly virus. Along with this, the fear of livelihood emerges when the newspaper gives more importance to deliver news about the corona virus's economic impact. Throughout the sample period, dailies especially The Daily Star, discussed the economic crisis due to this global pandemic. In some cases, newspapers mostly the ProthomAlo, tend to highlight human stories related to the novel virus. Precisely the study proves that both newspapers intend to frame the COVID-19 as a national crisis.

\section{Vil. Conclusion}

But as we are living in a pandemic situation, it's quite natural that the newspaper is publishing this type of news every day. Taking all the measures into account, it can be said that the selected newspapers had an intension to present the novel coronavirus as a threat to the nation, and in this regard, most of the articles are national focused. To minimize that risk, the government had tried to take actions, but the media did highlight more on limitations and unconscious mass of the country, which got people more feared. So it will be tough to conclude on this issue rather the newspapers can stop making catchy headlines representing deadly virus, which might get the newspapers some extra clicks, but it actually increases 'panic' among the general mass. Thus this article suggests that journalists should be more careful when they cover any specific issue related to the pandemic and its impact. Rather than disseminating fear, they can help to develop concerns of all parties to focus on the issues that can reduce its gruesomeness.

\section{References Références Referencias}

1. Anwar, S., Nasrullah, M., \& Hosen, M. (2020). COVID-19 and Bangladesh: Challenges and How to Address Them. Frontiers in Public Health, 8. https://doi.org/10.3389/fpubh.2020.00154

2. Aranda, Johnson. (2019). Media representations of the diseases of the 'other'-The coverage of 2014 Ebola Disease Virus in US network news. (n.d.). Retrieved July 28, 2020, from https://www. researchgate.net/publication/333916413 Media rep resentations_of the diseases_of_the_\% 27 other $\% 27$
The_coverage_of_2014_Ebola_Disease_Virus_in_U $S$ network news

3. Ashlin, A., \& Ladle, R. (n.d.). 'Natural disasters' and newspapers: Post-tsunami environmental discourse. Environmental Hazards, 7(4), 330-341.

4. Atasoy, I. (2020). Representations of the COVID-19 Pandemic in German and Spanish Newspaper Headlines: A Comparative Analysis.

5. Bangladesh Coronavirus: 137,787 Cases and 1,738 Deaths - Worldometer. (n.d.). Retrieved June 28, 2020, from https://www.worldometers.info/corona virus/country/bangladesh/

6. Bauer, M., \& Gaskell, G. (1999). Towards a paradigm for research on social representations. Journal for the Theory of Social Behaviour, 29, 163-186.

7. Daily Mail Online. (2020). China's coronavirus DID come from bats, study claims | Retrieved June 28, 2020, from https://www.dailymail.co.uk/health/ article-7960423/The-Latest-Shanghai-index-drops-8virus-outbreak-grows.html

8. Dhaka Tribune. (2020). Covid-19 in Bangladesh: A cruel choice between hunger and disease. (2020, May 4). https://www.dhakatribune.com/bangladesh /2020/05/04/covid-19-in-bangladesh-a-cruel-choicebetween-hunger-and-disease

9. Dhaka Tribune. (2020). Coronavirus: Bangladesh in top 20 countries with highest number of cases. (2020a, June 5). https://www.dhakatribune.com/ bangladesh/2020/06/05/coronavirus-bangladesh-intop-20-countries-with-highest-number-of-cases

10. Donovan, P. (1992). High noon in Bethesda: medicine, newsweeklies, adn the early phase of the AIDS epidemic. Proteus, 9(2), 11-19.

11. Höijer, Birgitta. (2011). Social Representations Theory. Nordicom Review. 32. 10.1515/nor-20170109.

12. Gaskell, G. (2001) Attitudes, Social Representations and beyond. In K. Deaux \& G. Philogene (Eds.), Social Representations: Introductions and Explorations. Oxford: Blackwell.

13. IEDCR. (n.d.). Retrieved June 28, 2020, from https://www.iedcr.gov.bd/index.php/component/con tent/article/73-ncov-2019

14. Kinsella, J. (1989). Covering the plague: AIDS and the American media. New Brunswick, NJ: Rutgers University Press.

15. Lerner, B. H. (2003). The breast cancer wars: hope, fear, and the pursuit of a cure in twentieth-century America. New York: Oxford University Press

16. Li Q, Guan X, Wu P, et al. (2020). Early transmission dynamics in Wuhan, China, of novel coronavirus-infected pneumonia [published online January 29, 2020]. N Engl J Med. 2020. doi:10. 1056/NEJMoa2001316 
17. Pew Research Center's Journalism Project. (2020). Americans Immersed in Coronavirus News; Most Think Media Are Doing Fairly Well Covering It. 2020, March 18. https://www.journalism.org/2020/03/18/ americans-immersed-in-covid-19-news-most-thinkmedia-are-doing-fairly-well-covering-it/

18. ProthomAlo. (2018). $6.6 m$ readership makes ProthomAlo highest read Bangladesh daily. Prothomalo. Retrieved July 28, 2020, from https://en. prothomalo.com/bangladesh/6.6m-reader ship-makes-Prothom-Alo-highest-read

19. Siddika, A., \& Islam, M. (2020). COVID-19 and Bangladesh: A study of the public perception on the measures taken by the government. https://doi.org/ 10.13140/RG.2.2.30042.49608

20. The Daily Star. (2020). Coronavirus: What ministers, leaders said. (2020, March 21). https://www.the dailystar.net/backpage/news/coronavirus-whatministers-leaders-said-1883698

21. The Guardian. (2020). First Covid-19 case happened in November, China government records showReport. (2020, March 13). http://www.theguardian. $\mathrm{com} / \mathrm{world} / 2020 / \mathrm{mar} / 13 /$ first-covid-19-casehappened-in-november-china-government-recordsshow-report

22. Van, dijk T. (2013). Ideology \& Discourse. M. Freeden. L.T. Sergant, M. Stears (ed). The Oxford Handbook of Political Ideology. 2013. Oxford. U.K. Oxford University Press.p.175-196.

23. Vaidyanathan, R. (2020, June 16). Bangladesh fears coronavirus crisis as cases rise. BBC News. https://www.bbc.com/news/world-asia-53054785

24. Wallis, P., \& Nerlich, B. (2005). Disease metaphors in new epidemics: The UK media framing of the 2003 SARS epidemic. Social Science \& Medicine, 60(11), 2629-2639. https://doi.org/10.1016/j. socscimed.2004.11.031

25. Washer, P. (2004). Representations of SARS in the British newspapers. Social Science \& Medicine (1982), 59(12), 2561-2571. https://doi.org/10.1016/j. socscimed.2004.03.038

26. Weiss, M. (1997). Signifying the pandemics: metaphors of AIDS, cancer, and heart disease. Medical Anthropology Quarterly, 11(4), 456-476 